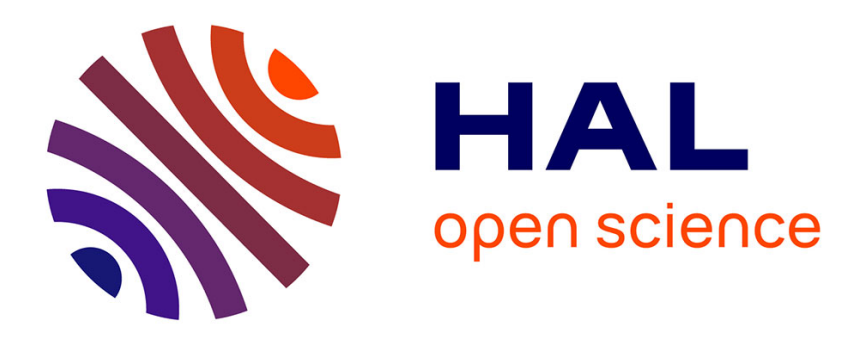

\title{
Four Arguments Against Compromising Justice Internally
}

\author{
Samantha Besson
}

\section{To cite this version:}

Samantha Besson. Four Arguments Against Compromising Justice Internally. Oxford Journal of Legal Studies, 2003, 23 (2), pp.211-241. 10.1093/ojls/23.2.211 . hal-02516227

\section{HAL Id: hal-02516227 \\ https://hal.science/hal-02516227}

Submitted on 3 May 2020

HAL is a multi-disciplinary open access archive for the deposit and dissemination of scientific research documents, whether they are published or not. The documents may come from teaching and research institutions in France or abroad, or from public or private research centers.
L'archive ouverte pluridisciplinaire HAL, est destinée au dépôt et à la diffusion de documents scientifiques de niveau recherche, publiés ou non, émanant des établissements d'enseignement et de recherche français ou étrangers, des laboratoires publics ou privés. 


\title{
Four Arguments Against Compromising Fustice Internally
}

\author{
SAMANTHA BESSON*
}

\begin{abstract}
This article examines whether legal compromise on matters of justice amounts to a desirable response to the problem raised by reasonable pluralism in politics. Attitudes toward compromise are ambiguous: it is generally seen as much as a valuable technique for settling conflicts by mutual accommodation as a prejudicial concession of one's integrity. The article aims to resolve this paradox by distinguishing cases where compromises of principle cannot be tolerated from those in which they can be. By developing Ronald Dworkin's distinction between internal and external compromises, the article shows that an internal compromise, that combines different conceptions of the same principle or of incommensurable and non-distinct principles, constitutes at the most a second-best alternative. Such a compromise fails to capture the core of our sense of law's intelligibility, justice, correct concept attribution and, finally, political integrity. By contrast, it is argued, external compromises of principle can be tolerated and may even be desirable in some cases. In fact, many conceptions of external compromise regard democracy as a paradigm of political compromise. This view is assessed at the end of the article and it is suggested that democratic procedures can be understood as compromises qua process: they select one of the conflicting views held during deliberation, rather than necessarily combining them into an externally compromised outcome.
\end{abstract}

\section{Introduction}

If there must be a compromise because people are divided about justice, then the compromise must be external, not internal; it must be a compromise about which scheme of justice to adopt rather than a compromised scheme of justice. ${ }^{1}$

Ronald Dworkin's reservations about what he also calls 'checkerboard'2 statutes have puzzled many of Law's Empire's readers. Checkerboard statutes compromise

\footnotetext{
* Dr. iur. (Fribourg), M. Jur. (Oxon.). Junior Research Fellow in Law, The Queen's College, Oxford and Lecturer, Law Faculty, University of Geneva. I thank the Swiss National Science Foundation without whose support I could not have pursued this research. Earlier drafts of this paper were delivered at a research seminar in jurisprudence and political theory, University of Oxford, May 2001 and at the IVR World Congress, Amsterdam, June 2001. I would like to thank all participants for their comments and criticism, and in particular Leslie Green, Scott Hershowitz, Wojciech Sadurski and Dale Smith. My special thanks to Nicos Stavropoulos for his detailed critiques, to John Gardner for his helpful suggestions, as well as to Nick Barber for his invaluable linguistic advice. I am also grateful to an anonymous referee for his or her comments; they enabled me to improve this paper considerably.

1 R. Dworkin, Law's Empire (1986) at 179.

2 See Dworkin, above $\mathrm{n} 1$ at 435, n 6: checkerboard statutes are 'statutes that display incoherence in principle and that can be justified, if at all, only on grounds of a fair allocation of political power between different moral parties'.
} 
principles internally, that is to say in an unprincipled way, by allowing all competing conceptions of the principles at stake to be reflected in the rules produced even if some of them are wrong or inconsistent, hence the checkerboard metaphor. This is the case, for instance, of a statute that compromises the right to life by allowing abortions for women with blue eyes only.

In spite of persistent reasonable disagreement about justice, there is often a need to converge on a single rule in some pressing matters. This could sometimes even lead to compromising some of our views. But should we then really limit ourselves, as Dworkin suggests, to compromising externally about which of two or more concepts or conceptions of justice to adopt rather than proceed with a compromise internal to the content of our normative concepts of justice? The issue addressed in this article is the extent to which compromises on matters of justice are a desirable response to the problem raised in politics and the law by reasonable pluralism and the need to find a settlement of our moral conflicts.

Many of us share an instinctively hostile reaction towards legal compromises over matters of principle which attempt to integrate conflicting conceptions of the same concept ${ }^{3}$ or in which the content of one principle is compromised with unreasonable ${ }^{4}$ conceptions of another principle. ${ }^{5}$ In fact, most of us regard justice, as John Rawls claims we should, as the uncompromising virtue of human activity that should have priority over any other consideration. ${ }^{6}$ But how do we reconcile these intuitions with the respect we owe to reasonable disagreement over moral issues and with the duties of mutual accommodation in the law which we sometimes see as a consequence and which urge us to do more than simply camp on our dogmatic positions until a vote decides one way or the other? ${ }^{7}$ Furthermore, how can we explain our hostility towards compromise

\footnotetext{
They 'treat similar accidents ... differently on arbitrary grounds' (Dworkin, above $\mathrm{n} 1$ at 179). In this paper, I regard checkerboard statutes as the product of internal compromise and will only concentrate on the latter; when an internal compromise is struck between a principle and something else, the result is not principled and the way in which some cases are treated accordingly cannot be principled either. I do not intend, however, to discuss his approach to checkerboard statutes per se nor, more generally, his argument for integrity or coherence in the law as a whole; I will borrow some of his arguments, but am not endorsing nor defending Dworkin's account of integrity.

${ }^{3}$ I will assume in this article that the argument one can make about unprincipled exceptions to a principle is analogous to the one that can be made about unprincipled exceptions to concepts.

4 I will not expand here on the notion of reasonableness, but let me briefly summarize my position: the kind of reasonableness that matters here is the reasonableness of a person, who in goodwill and given her entire personal circumstances, applies her reasoning capacities to a question, even if her position is something we regard as morally wrong, provided it is plausible in her circumstances.

5 See Dworkin, above $\mathrm{n} 1$ at 178, 182: 'We would prefer either of the alternative solutions to the checkerboard compromise'. On the lawyers' general reticence concerning moral compromise, see J.E. Coons 'Approaches to court-imposed compromises: the uses of doubt and reason', 58 Northwestern University Law Review 750 (1964).

${ }^{6} \mathrm{~J}$. Rawls, A Theory of fustice (1971) at 3. See, however, for a critique of Rawls' own compromising of justice and equality through the difference principle, G.A. Cohen, 'Incentives, Inequality and Community' in Tanner Lectures on Human Values (1992) 261 at 314, 328-9.

7 Contra Gutmann and Thompson, Democracy and Disagreement (1996), I do not regard mutual accommodation as encompassing deliberation; mutual accommodation is needed when it is clear that deliberation has not provided the parties with a settlement of the dispute. See A. Wertheimer, 'Internal Disagreements: Deliberation and Abortion' in S. Macedo (ed.), Deliberative politics, Essays on Democracy and Disagreement (1999) 170.
} 
of principle within the law ${ }^{8}$ in the face of the widespread practice of bargaining and compromising over matters of fact, interest and even, sometimes, of principle within the political arena? ${ }^{9}$

In brief, then, attitudes toward moral compromise in politics are ambiguous. ${ }^{10}$ This ambiguity is even reflected in the definitions of the concept of compromise. Compromise is commonly seen as a fair technique for dealing with moral and legal pluralism and for settling conflicts by mutual concessions, but it is also sometimes regarded as hypocritical surrender. It seems difficult to draw a line between compromising one's moral convictions and compromising oneself and one's integrity. There is, in other words, an 'air of paradox' around the connection between morality and compromise: commitment to a moral principle means commitment to seeing it fully realized. ${ }^{11}$ But, in the context of everyday democratic politics, when faced with reasonable disagreement, commitment to a moral principle may require us to be willing to compromise to some extent or, at least, to express moral goodwill and respect towards accommodating other people's conflicting positions. ${ }^{12}$ The difficulty is that this will frequently amount to partially, or even completely, abandoning the principle defended in the first place. I will argue that this paradox can be explained away or tempered by distinguishing cases where moral compromises cannot be tolerated from cases where they can be or even are desirable. ${ }^{13}$ Although compromises may have a positive role to play in democratic politics, the latter should not necessarily be reduced to the 'institutionalized art of compromise'. ${ }^{14}$

My aim in this article is to examine the extent to which our shared intuition against some compromises of principle is well-founded. First, I will draw a few distinctions inherent to the contestable concept of compromise. Second, I will discuss the prima facie justification of the various forms of moral compromise that may be reached in politics depending on the type of conflict and the principles at stake. Third, I will examine the limitations and dangers of some forms of moral compromise. More specifically, I will advance four arguments showing why

\footnotetext{
${ }^{8}$ I will restrict the scope of my analysis to moral compromises in the political process of law-making, rather than discuss the issue of political compromise of interests or the broader issue of moral compromise tout court. Note, however, that I do not share some authors' view (e.g. M. Benjamin, Splitting the Difference, Compromise and Integrity in Ethics and Politics (1990) at 1) who accept political compromises much more easily than moral ones, independently of any further qualification of the former's content; not all political compromises are compromises of interests and moral compromises in politics raise questions that are as complex as in the purely moral realm. I will come back to this point in the course of the essay.

9 It is common in the legal and political literature to understand democratic deliberation about justice as being not only oriented towards agreement, but also towards compromise as a more realistic form of mutual accommodation. See, for instance, J.P. Müller, Demokratische Gerechtigkeit (1993) at 148 who speaks of 'konsens-oder kompromissorientierten Diskurse über Richtiges'.

10 J. Carens, 'Compromises in Politics' in Pennock and Chapman (eds), Nomos 31: Compromise in Ethics, Law and Politics (1979) $123 \mathrm{ff}$.; Benjamin, above n 8 at 4, $8 \mathrm{ff}$. See also P. Singer, Democracy and Disobedience (1974) at 40 by reference to Thoreau: 'The notion of a compromise, many people seem to feel, is somehow degrading and incompatible with the idea of acting according to moral principle'.

11 A. Kuflik, 'Morality and Compromise' in Pennock and Chapman (eds), Nomos 31: Compromise in Ethics, Law and Politics (1979) 38.

12 See C. Cohen, Democracy (1971) at 181-2.

13 See J. Halowell 'Compromise as a Political Ideal' (1944) 54 Ethics 158 at 173.

14 T.V. Smith 'Compromise: Its Context and Limits' (1942) 53 Ethics 1 at 2.
} 
compromise over justice that strikes a balance between conflicting conceptions of the same moral principle, or between conflicting principles one of the parties ${ }^{15}$ does not endorse or recognize as reasonable, is not desirable in the law and does not provide an adequate settlement of reasonable disagreement. In the fourth and last section I will assess the common the identification of democratic procedures with paradigms of compromise.

\section{The Concept of Compromise}

\section{A. A Few Distinctions}

At the most basic level, there are two rather different ways of understanding what is meant by 'compromise', depending on whether the focus is on the process or the outcome dimension of compromise.

In an outcome or 'end-state' analysis, the resolution of a conflict can be characterized as a compromise if it results in some gain and loss for all, regardless of how the compromise was reached. This conception of compromise seems to be the one we use when we speak of 'imposing a compromise solution'; the implication of this phrase is that compromises are outcomes that can be characterized as such without reference to the process by which they are achieved.

According to the 'process' analysis, by contrast, a compromise is a certain way of achieving conflict resolution through 'give and take' by each party and mutual accommodation of their differences, whatever the actual terms of the final settlement might be. ${ }^{16}$ This is the case when the parties have agreed to submit their dispute to the determination of a certain procedure, such as the democratic procedure. ${ }^{17}$ Such a conception of compromise is used when we speak of 'reaching a solution through compromise'; it suggests that compromise is not an end result, but rather a special process for generating end results. It is interesting to note that, like compromises qua outcome, compromises qua process need not be the outcome of a compromise qua process themselves. Nor need they be the outcome of a compromise qua outcome; there could be consensus on using the majority rule, for instance.

Although both dimensions may be encountered separately, what is understood as the standard case of compromise usually meets both characteristics. ${ }^{18}$ The standard compromise amounts both to a procedure of 'give and take' and to an outcome that results in some gain and loss for all. It is important, however, to

\footnotetext{
${ }^{15}$ I will focus, for the purpose of clarity, on dual conflicts and compromises, i.e. pure conflicts and compromises between two distinct principles, although political debates are rarely so bi-polarized in practice; people confront ethical decisions with all their principles and very often what seemed like a compromise between two principles will in fact affect other principles, such as the principle of non-discrimination for instance, thus undermining in some cases the advantages gained from compromising and preventing it from looking like a compromise at all.

${ }^{16}$ See Kuflik, above n 11 at 39-40; M. Golding, 'The Concept of Compromise: A Preliminary Inquiry' in Pennock and Chapman (eds), Nomos 31: Compromise in Ethics, Law and Politics (1979).

17 See Benjamin, above $\mathrm{n} 8$ at $6-7$.

18 Kuflik, above n 11 at 40; Benjamin, above $\mathrm{n} 8$ at 12 .
} 
keep this distinction in mind in order to avoid dangerous confusion, particularly about the role of compromise qua outcome within democratic procedures, as we will see in the last section of this paper.

In the standard case of compromise qua outcome, to which I will be referring unless otherwise specified, a compromise amounts to a settlement that is not constitutive of a real agreement. It is usually reached by negotiation on some 'middle ground' that 'splits the difference' and 'gives something to each side'. ${ }^{19}$ Such compromises may be accepted by the parties for different reasons and justifications: ${ }^{20}$ parties who cannot agree on A or B will accept compromise C even though none of its components is acceptable separately to either of the parties. It is therefore important to distinguish the true agreement, ${ }^{21}$ i.e. the full 'endorsement' of the content of $\mathrm{C},{ }^{22}$ from the 'acceptance' of $\mathrm{C}$ as the outcome of a compromise. ${ }^{23}$ The distinction therefore corresponds in a sense to the distinction between true consensus and mere convergence on a modus vivendi, although not all modi vivendi are necessarily compromises.

It is possible to distinguish two main types of compromise qua outcome when applied to matters of principle, depending on whether or not the trade-off affects the content of one of the principles in a principled way. ${ }^{24}$

First, external compromises. These are compromises about which principles or conceptions of justice should be adopted. ${ }^{25}$ More precisely, external compromises only affect the content of the principles or conceptions of justice at stake in a principled way. The exceptions made are principled, because they are based on another independent principle or conception. Hence, one could say that the outcome amounts to a third and independent principle, conception or scheme of justice, rather than a compromised one. For instance, although equality-based restrictions on public display of pornography are in one sense a compromise of the moral independence of pornography consumers, this compromise is recommended by the principle of moral independence itself, albeit limited in a principled way, and hence constitutes a new scheme of justice derived from moral independence. $^{26}$

External compromises can be either distributive or integrative. ${ }^{27}$ Distributive compromises split the difference by giving both parties some of their claims,

\footnotetext{
19 See S. Macedo, Liberal virtues: citizenship, virtue and community in liberal constitutionalism (1991) at 72.

20 See J. Habermas, Faktizität und Geltung, Beiträge zur Diskurstheorie des Rechts und des demokratischen Rechtsstaats (1998) at 205.

21 The term 'agreement' is ambiguous and is generally used, depending on the context, to indicate either the full endorsement and the belief in a principle or the mere acceptance of that principle.

22 See Boltanski and Thévenot, De la fustification, Les économies de la grandeur (1991) at 337: 'Dans un compromis, on se met d'accord pour composer, c'est-à-dire pour suspendre le différend, sans qu'il ait été réglé par le recours à une épreuve dans un seul monde. La situation de compromis demeure composite, mais le différend est évité'.

23 See D. Luban 'Bargaining and Compromise: Recent Work on Negotiation and Informal Justice' (1985) 14 Philosophy and Public Affairs 397 at 417.

24 This distinction should not be confused with Benjamin's (above n 8 at 20) distinction between external compromises, that take place between people, and internal compromises, that take place within oneself.

${ }^{25}$ Dworkin, above $\mathrm{n} 1$ at 179.

26 See R. Dworkin, A Matter of Principle (1985) at 365.

27 See Carens, above n 10 at 126-7 on the plurality of possible compromises along a continuum.
} 
either alternatively or at the same time; such compromises are slightly more satisfactory to both sides than failure to reach agreement at all. For instance, one party might agree on a progressive tax scheme that protects the poor in one case, in exchange for an agreement to renounce a social protection law that would impinge on rich people's property in another. By contrast, integrative compromises amount to a new understanding of the issue combining both conceptions or principles into a more complex and principled one. ${ }^{28}$ The question may arise, for example, whether inheritance tax is just. Suppose, for instance, that people disagree over the justice of this tax in virtue of supporting, on the one hand, the freedom to use one's private property as one wishes and, on the other, the equality of resources in society in general. An integrative compromise could take the form of a scheme of inheritance tax which recognizes both principles in a certain relation by setting tax rates that are less than confiscatory. Such ad hoc principled compromises should be distinguished from naturally compromised concepts, that is to say cases where a principled compromise is already conceptualized within an independent and coherent rule. The principle of paying one's creditors pro rata provides an example of this. ${ }^{29}$

Second, internal compromises. These amount to 'compromised schemes of justice ${ }^{30}$ in the sense that they affect the content of the chosen principle or conception of justice in an unprincipled way. The exceptions made to the principles or conceptions concerned are not based on another independent principle or conception. An example of a compromised scheme of justice such as this could be a tax cut scheme that justifies restrictions to the principle of equality by reference to efficiency and economic incentive concerns; these concerns are not usually regarded as independent principles. ${ }^{31}$

In the political and legal context, as opposed to a purely private context of bilateral bargaining, ${ }^{32}$ compromises can be struck by officials in very different institutions. Some authors have thus distinguished between judicial $l^{33}$ and legislative compromises. In the present paper, I will not focus on any particular form of institutional compromise, ${ }^{34}$ but rather concentrate on their common feature

\footnotetext{
${ }^{28}$ See on the origins of this distinction, M. Follet, 'Constructive Conflict' in Metcalf and Urwich (eds), Dynamic Administration: The Collected Papers of Mary Parker Follet (1940).

29 See Coons, above $\mathrm{n} 5$ at 788.

30 Dworkin, above $\mathrm{n} 1$ at 179.

31 See Cohen, above $\mathrm{n} 6$ at 313-14, 328-9 criticizing Rawls' difference principle on that very basis.

32 In this article I will not discuss the different methods of settlement that can lead to a privately negotiated compromise. See e.g. Kuflik, above n 11 at $52 \mathrm{ff}$.

${ }^{33}$ See Coons, above n 5 at 753 who concentrates purely on judicial or 'imposed' compromises, i.e. 'the apportionment of right and duty between opposed litigants by a court according to a quantitative standard that is not limited to the favouring of one party to the exclusion of his adversary'.

${ }^{34}$ I will not enter here into the political argument that opposes the role of adjudication in attributing concepts and determining what they are, to the more modest role of the legislature, that would allegedly restrict its function to determining what should be done in a particular case as opposed to what is the content of some moral principle; when the legislature deliberates as to what should be done, the issue of what the different principles at stake imply will necessarily be raised and the final decision will therefore reflect a view on what those concepts are. Moreover, the legislature is democratically more legitimized to establish the content of concepts than judges, who are less representative despite their greater independence and who suffer from the same or even worse (given their smaller number) epistemic limitations. Thus, if someone must make compromises within the law, it should be the legislature rather than the judiciary.
} 
when applied to conflicts of principle. ${ }^{35}$ Perhaps the most interesting common feature of institutional forms of compromise qua outcome is the weighing and balancing of the divergent principles or conceptions of the same principle; these may be brought before the institutions by individuals or may actually be part of the process of deliberation. Parties to the compromise are the officials in charge of the deliberation, such as representative members of a legislative assembly or judges. True, officials will often be called on to settle a dispute to which they are not party in the sense that they hold either one of the views disputed, and they will settle on one particular conception or principle at stake in the dispute. In such a case, compromise will not be manifested in the official decision. ${ }^{36}$ This rests on the assumption that democratically chosen officials should have justice in mind, and deliberate and vote on the grounds of what they think is the right or best answer for the community as a whole, ${ }^{37}$ and not of what the parties to the dispute before them or other non-represented interest groups believe. ${ }^{38}$ Before proceeding with the discussion of the justification and limitations of compromise of principles, a caveat is in order.

\section{B. A Caveat: The Disagreeable Nature of Compromise}

Compromise is one response to controversy over moral matters. As such, it should come as no surprise that the very concept of compromise is a contestable one. This contestability occurs at different levels.

First, people might not only disagree about what is the proper justification principle in their dispute, but also about whether they should actually compromise at all. ${ }^{39}$ The broader issue raised here is that reasonable disagreement over the justice and fairness ${ }^{40}$ of a substantive matter extends to the justice and fairness

\footnotetext{
35 I am not questioning the differences in content among the disagreements at stake before the legislature and the judiciary - it is true that there will be more disagreements (and hence compromises) of interests within legislative deliberations than within judicial ones, for instance-but only the differences in form among the compromises reached to settle disagreements of principle.

36 This may be the case when the parties do not agree on any precise compromise or are not entitled to settle their difficulties privately.

37 I disagree therefore with some authors' idea that a politician cannot but have dirty hands and take the responsibility of doing things he thinks are morally wrong. See for instance M. Walzer 'Political Action: The Problem of Dirty Hands' (1973) 2 Philosophy and Public Affairs 160. Contra T. Nagel, 'Ruthlessness in Public Life' in Mortal Questions (1979) at 74 and, most famously, M. Weber, 'Politics as Vocation' in Gerth and Wright Mills (eds), From Max Weber: Essays in Sociology (1991) 77.

38 Thus, I do not agree with the idea some authors present that, when the official has no dilemma of her own on some issue or the officials have no disagreement with each other, they should, however, attempt to accommodate the diverging views of others in the community and of the parties in the procedure for instance through actual compromises; the principles of mutual respect and accommodation of our differences only hold among people who are situated within the same sphere of discourse and deliberation, such as, in this case, the officials themselves. This applies, of course, within the limits of some basic form of continuity and coherence with past decisions and laws; the principle of legal coherence and the efforts it implies for an official to replace her decision within her community's principles and past decisions as a whole prevent conflicts between officials' current and past conceptions of justice. Interestingly, coherence can, albeit not necessarily, lead in some cases to the adoption of external compromises.

39 This is provided, of course, that none of the criteria usually applied to settle conflicts of principles find application or remain uncontroversial. These criteria are, among others, the hierarchical criterion, the chronological criterion or the criterion of speciality.

40 I am not using 'justice' and 'fairness' in the restrictive Dworkinian sense of the terms.
} 
of either the decision-making procedures for resolving the dispute or the type of settlement. ${ }^{41}$ Faced with this difficulty, ${ }^{42}$ some proponents of compromise have claimed that moral judgement is the sole basis for the choice of compromise over other alternative forms of dispute settlement. ${ }^{43}$ It is to such arguments that I will turn when assessing the justification and limitations of compromise of principles.

Second, even when people agree to compromise, when asked to do so with a conception they do not endorse, they may disagree over the reasonableness of that conception ${ }^{44}$ and thus over the moral desirability of a particular compromise.

Third, even when they have agreed to a particular compromise, people might still disagree on what constitutes the right compromise between their competing views of justice. ${ }^{45}$ As we saw before, there may be many possible compromises along a continuum ranging from purely distributive compromises to integrative ones. Integrative compromises, for instance, may be reached either by simply splitting the difference along a continuum of possibilities or by splitting it along the lines that are dictated by an independent mediating principle agreed on by the parties. Some authors have argued that, all else being equal, any division other than 'fifty-fifty' discriminates against one party. ${ }^{46}$ There is, however, no reason why both parties should always agree on such a principle of 'equality in indeterminacy' and meeting half-way once they have agreed on compromising. ${ }^{47}$ This ranking decision is made even more difficult when what is compromised over is neither divisible nor evaluable in monetary terms such as certain matters of principle. An example here might be the difficulty in striking an integrative compromise between the principles of desegregation and of equal facilities within the meaning of the principle of equal protection of the laws.

Finally, even if the parties can agree on the best 'middle ground', specific interpretations of that compromise will engender further persistent disagreements. ${ }^{48}$ These disagreements might then in turn call for further compromises. All these controversies show that compromise is neither an easy nor a definitive answer to disagreement, even when it is justified by the criteria I shall turn to now.

\footnotetext{
41 See also Smith, above n 14: 'Ideals (justice for example) cannot be invoked to settle issues that involve quarrels as to what the ideals are'. On this issue of regress, see J. Fishkin, 'Liberal Theory and the Problem of Justification' in Pennock and Chapman (eds), Nomos 27: Fustification (1986) at 217.

42 Like Dworkin, above $\mathrm{n} 1$ at $180 \mathrm{ff}$., I do not think that a general and objective argument of justice (or fairness, as a matter of fact [contra Dworkin, above $\mathrm{n} 1$ at 179]) can be used as an argument for or against internal compromise independently of what the parties hold of the latter's justice. My reasons, however, are related to reasonable disagreement about these principles.

43 See Benjamin, above $\mathrm{n} 8$ at $107 \mathrm{ff}$.

44 See for this instance of second-order disagreement, Wertheimer, above $\mathrm{n} 7$ at 174 . See for an example of the avoidance of this problem, Macedo, above n 19 at 75 who refers to the reasonable substance of moderation.

${ }^{45}$ G. Gaus, fustificatory Liberalism: An Essay in Epistemology and Political Theory (1996) at 183. See also Carens, above $\mathrm{n} 10$ at 126,137

46 Coons, above $\mathrm{n} 5$ at 759,803 .

47 Contra Benjamin, above n 8 at 33; G. Sher 'Subsidized Abortion: Moral Rights and Moral Compromise' (1981) 10 Philosophy and Public Affairs 361 at 370; Kuflik, above n 11 at 50. See for an example of this second-order form of disagreement, Gutmann and Thompson's (above $n 7$ at 88-9) critique of Sher's solution of a reasonable compromise on abortion.

${ }^{48}$ Gaus, above n 45 at 183-4.
} 


\section{The fustification of Compromise}

\section{A. General}

The justification of moral compromise in politics ought to be argued for on a specific basis. Given the diversity of the objects of moral disagreement and its different shapes, the desirability of moral compromise is bound to vary. In order to assess its desirability, then, it is necessary to do so in the light of specific types of political conflicts. I propose to distinguish between the desirability of compromises of interests and of compromises of principles. ${ }^{49}$ This second category will then be further divided between multi-principle and single-principle compromises.

It is important to remember that talking of justification or desirability here is slightly exaggerated. The essence of the argument in this article is primarily negative; it simply aims to articulate the justifications underpinning the negative intuitions people share against some types of compromise of justice. It does not aspire to provide a general positive justification of the other prima facie morally desirable types of compromises. ${ }^{50}$ In order to undertake this task, the article first distinguishes the types of compromise that prima facie strike our intuitions as being tolerable from those that do not, without arguing for the adoption of apparently tolerable compromises. Second, it seeks to explain why the types of compromise that were identified as not being prima facie tolerable should be avoided.

The remainder of this section corresponds to the first prong of the argument. First, whilst I will not attempt to establish the moral desirability of strategic compromises of interests and facts, I will explain why I think they should be tolerated when they take place. Second, I will then seek to distinguish compromises of principle that should be tolerated from those that should not be.

\section{B. Compromise of Interests}

In a political community not every conflict is generated by conflicting moral opinions. Difference in taste, preference or interests can also set people at odds. To borrow a famous example, let us imagine that I want to play the trumpet one evening and you want to do some algebra at the same time in the next apartment. ${ }^{51}$ As long as competing interests are compatible with basic rights and as long as what is at stake in the conflict is not their legitimacy or ethical

\footnotetext{
${ }^{49}$ In spite of its widespread use in this context and elsewhere, it is incredible how this distinction is difficult to justify and maintain in most cases where matters of interest and of principle are intertwined; for instance, creating random parking zones will limit people's freedom of movement and the principle of equal treatment, etc. I will, however, for reasons of space, have to leave this issue for another paper.

${ }^{50}$ Hence I leave aside the complex dilemma between priority or hierarchy, on the one hand, and conciliation or compromise, on the other, in case of conflicts of rights or principles. It suffices for the purpose of my article to argue that, whether or not there are some arguments for compromising in some cases of conflict of principles, these arguments do not hold in the case where the compromises are internal to those principles.

${ }^{51}$ See Dworkin, above $\mathrm{n} 1$ at $302 \mathrm{ff}$.
} 
importance, ${ }^{52}$ there is no moral obstacle to a compromise of interests. Interests and preferences are naturally divisible, as opposed to matters of principle which often form coherent wholes. ${ }^{53}$

In some cases, compromise of interests is not only tolerable but desirable. This is the case, for instance, when we would gain more from a compromised settlement than from failure to reach one. ${ }^{54}$ We therefore often accept splitting our differences of interests along any line, as long as doing so makes us all happy. This could be instantiated by the case of zoning, where parking spaces have to be distributed and a line drawn between certain areas. Such compromises are therefore often referred to as strategic compromises.

To illustrate this argument for the justification of strategic compromise, let us think of a case of factual uncertainty. ${ }^{55}$ In this case, the application of a rule or principle can be based on no greater probability of factual accuracy on either side of the dispute and the interest at stake is divisible, as when it is evaluated in money. For instance, one could imagine a paternity suit where the probabilities of paternity as well as the monetary support to the child are divisible objects. Such objects are easily compromised over when the factual evidence is uncertain and the parties who agree on the principle make conflicting claims of facts and interests. ${ }^{56}$ In such a case, dividing what is at stake between the parties seems like a fair solution. ${ }^{57}$

Given the general desirability of compromises of interests in democratic politics, some proponents of the validity of compromises in the law have tried to identify conflicts of principles in politics with conflicts of interests. ${ }^{58}$ This has had regrettable consequences. Most cases of disagreement over principles of justice are not comparable to cases where the parties oppose their individual interests, ${ }^{59}$ though they may be intertwined. ${ }^{60}$ This liberal tendency to transform moral conflicts over principles into conflicts of interests masks the importance of moral disagreements in politics. ${ }^{61}$

52 Benjamin, above $\mathrm{n} 8$ at $15-17$.

53 See Benjamin, above $\mathrm{n} 8$ at 7 ; Dworkin, above $\mathrm{n} 1$ at 179.

54 Habermas, above $\mathrm{n} 20$ at $204-5$.

55 Questions of facts and questions of value are often closely intertwined, thus making this distinction difficult.

56 See J. Elster, Solomonic fudgements, Studies in the Limitations of Rationality (1989) at 100.

57 See Coons, above n 5 at 757.

58 It is interesting here to illustrate the distinction between compromises in matters of interests and compromises in matters of justice, with the Swiss mode of governance. The latter is characterized mainly by the ancient German model of governance which regards the common interest as a sum of particular interests rather than as something distinct from them. This conception of democratic politics explains the Swiss attachment to compromise and to the so-called 'concordance-democracy'. See, e.g. V. Büchler-Tschüdin, Demokratie und Kompromiss (1980) at 35. For a critique, see M. Lendi, 'Konsens-Fähigkeit zum Dissens' in Recht als Prozess, Festschrift Hans Huber (1981) 490 at 497 who speaks of 'Konsens-verkrampfung'.

59 See Rawls, above n 6 at 3: 'The rights secured by justice are not subject to political bargaining or to the calculus of social interests'.

${ }^{60}$ See Carens, above n 10 at $130-1$.

61 See I. Berlin, 'Does Political Theory Still Exist?' in Laslett and Runciman (eds), Philosophy, Politics and Society (Second Series, 1969). On the opposite view, i.e. the emotivist conception of political settlements of conflicts as being bare compromises of subjective interests and preferences at the most, see R. Rorty, Contingency, Irony and Solidarity (1989) at 68 according to whom 'all that is in question is accommodation, not synthesis'. 


\section{Compromise of Principles}

\section{(i) General}

Unlike conflicts of private interests that are to be reconciled one way or another, differences between judgements of justice could prima facie be regarded as unsuitable for compromise. ${ }^{62}$ By contrast to interests, moral principles are not necessarily divisible entities. ${ }^{63}$ In some conflicts of principles or conceptions of what those principles amount to in a particular case, however, compromise might be seen as a tolerable or even desirable settlement of reasonable disagreement.

In fact, many authors regard moral compromise as the appropriate answer to moral disagreement given the conditions of scarcity, uncertainty and complexity, that is to say the burdens of judgement that are typical of modern democratic politics. The circumstances of reasonable disagreement combined with the political need for a settlement ${ }^{64}$ have even been described as the 'circumstances of compromise', ${ }^{65}$ by analogy to David Hume's 'circumstances of justice'.

According to George Sher, for instance, a moral compromise is appropriate if the 'grounding' of one's principles is 'problematical', if the opposing view is supported by 'plausible sounding arguments', and 'if thoughtful and intelligent people are unable to agree about the issues'. By accepting a 'higher-order moral principle' of this sort, 'we acknowledge both our own fallibility' and show respect for the status of others beside ourselves as moral agents. ${ }^{66}$ This duty of respect should lead the parties to tolerate and even to accommodate each other's views as much as possible, thus calling in some cases for compromises that will amount to showing even more respect for one's opponents' views than other forms of mutual accommodation. ${ }^{67}$

Sher's contention ignores the possibility that a respectful and peaceful accommodation or settlement may also be achieved by other means that show just as much respect for the other party's view as compromising ${ }^{68}$ does and yet go

\footnotetext{
${ }^{62}$ See Habermas, above n 20 at 206: 'Weil die Kompromissbildung moralische Diskurse nicht ersetzen kann, lässt sich die politische Willensbildung nicht auf Kompromissbildung reduzieren'.

${ }^{6}$ See Dworkin, above $\mathrm{n} 1$ at $178-9$. See also Benjamin, above $\mathrm{n} 8$ at 7 on external compromise over matters of principle which does not necessarily entail an internal compromise, for principles are 'indivisible goods'. It is interesting to see, however, that Carens' (above n 10 at 125) example of a donor who has to divide a sum of money, that is by essence a divisible good, between two researchers does not adequately illustrate the distinction Carens wants to draw between compromises of principle and compromises of interests in case of uncertainty as to the right answer.

${ }^{64}$ See for an example of the attractive nature of compromise in politics where we need to act on the basis of a single rule or decision, Carens, above n 10 at $124 \mathrm{ff}$.: Carens contrasts the case of two eminent scientists who hold competing theories about the causes of cancer with the case of a donor who has to decide to which of them to give two million dollars; in the first case, a compromise is neither necessary nor appropriate for the two scientists will pursue their research until one of their theories is either proved or refuted, whereas in the second case, the donor is forced to act in the face of uncertainty and has to choose between giving the sum to the scientist he thinks is best given the circumstances, on the one hand, and splitting the amount between the two, on the other.

${ }^{65}$ Benjamin, above $\mathrm{n} 8$ at $24 \mathrm{ff}$.

66 Sher, above n 47 at 369.

${ }^{67}$ See among others Kuflik, above n 11 at 51; Sher, above n 47 at 369; Benjamin, above n 8 at 72 ff.; D. Dobel, Compromise (1990); Macedo, above n 19 at 71-2; Gutmann and Thompson, above $\mathrm{n} 7$ at 88-9.

${ }^{68}$ See for instance Smith, above n 14 at 2 who holds that dictatorship is the only alternative to compromise: 'It is this convergence that makes an ethical enterprise out of politics, which is the institutionalized art of compromise'. See also Benjamin, above $\mathrm{n} 8$ at 32 who identifies the circumstances of disagreement and the need to converge with the circumstances of compromise. See also Kuflik, above n 11 at 51 and Carens, above n 10 at $126 \mathrm{ff}$. See also, in the rational choice context, Elster, above n 56 at 99: 'Resistance to compromise must be due to the resistance to acknowledging the indeterminacy of fact or law'.
} 
further than mere toleration. ${ }^{69}$ This can be done, on the one hand, by settlements which promote mutual accommodation in a way that leads to a better understanding of the other position or even to a change of opinion ${ }^{70}$ or, on the other, by fair procedures that can be used to choose between the options at stake.

Part of the ambiguity that surrounds the justification of compromise in this respect is nourished by confusion about its exact meaning; some authors have conflated compromise with broader forms of 'mutual accommodation ${ }^{, 71}$ or 'principled moderation', ${ }^{72}$ of which compromise qua outcome is in reality only one type. ${ }^{73}$ Principles of accommodation are based on mutual respect for diverging positions. ${ }^{74}$ They only require, however, that people try, even when they disagree reasonably, 'to accommodate the moral convictions of their opponents to the greatest extent possible, without necessarily compromising their own moral convictions' ${ }^{75}$ The parties could, for example, continue to reason together to reach 'mutually acceptable decisions' ${ }^{76}$ by trying to understand the others' position better and by being ready to amend or change their own completely. ${ }^{77}$

Besides, the respect-based argument could even be said to strengthen the objection against compromise. Once the parties have accepted the desirability of reaching a settlement given the awareness of their mutual fallibility, the reasonableness of the other party's view will call for more respect than the potentially equally mistaken, or even more mistaken 'halfway' third view; this halfway position might not be reasonably held by anyone as a conception of justice per se. ${ }^{78} \mathrm{As}$ a result, when the political community needs to act on a single view of justice, the parties will generally be more motivated out of respect to accommodate the other party entirely or to compromise procedurally in abiding by the outcome of a democratic vote choosing one of the views at stake, for example.

In response, some authors have invoked the right to self-respect of the party, that would otherwise be called to bear the entire burden of the settlement out of respect for the other party's view. ${ }^{79}$ They argue that people cannot but choose to preserve the overall pattern of their lives as far as possible, even when compromising it to a certain degree, rather than upset it to the extent necessary to defer to

\footnotetext{
${ }^{69}$ Contra Sher, above $\mathrm{n} 47$ at $367-8$ for whom there is no middle path between tolerating abortion and compromising over it.

${ }^{70}$ See D. Wong 'Coping with Moral Conflict and Ambiguity' (1992) 102 Ethics 777 at 780-2 who recommends compromise as one of the many principles of mutual accommodation only.

${ }^{71}$ Gutmann and Thompson, above $\mathrm{n} 7$ at 44, 88. For instance, the definition of compromise given by J. Bohman 'Public Reason and Cultural Pluralism, Political Liberalism and the Problem of Moral Conflict' (1995) 23 Political Theory 253 at 263 corresponds to a general conception of mutual accommodation rather than of compromise stricto sensu. See also partly J. Waldron, Law and Disagreement (1999) at 204.

${ }_{73}$ Macedo, above n 19 at 72.

${ }^{73}$ See Lendi, above $\mathrm{n} 58$ at 491.

74 See Macedo, above n 19 at 72 ; Gutmann and Thompson, above $\mathrm{n} 7$ at 79 .

75 Gutmann and Thompson, above $\mathrm{n} 7$ at 3 (emphasis added).

76 Ibid at 1 .

77 Ibid at 85 .

78 See Luban, above n 23 at 415.

79 See Kuflik, above n 11 at 50-1; Benjamin, above n 8 at 37.
} 
a principled solution that others might prefer. This argument ignores, however, an important dimension of the problem. Self-respect is partly based on the respect one shows to other reasonable moral agents and cannot therefore be opposed to respect for others. It cannot lead to the adoption of a half-way solution that lacks true respect for them. Moreover, if respect for others cannot support a hybrid position which nobody actually defends before the compromise takes place, respect for oneself, a fortiori, cannot lead one to accept such a position.

Another counter-argument may be found in Jeremy Waldron's account of the circumstances of political integrity or coherence, ${ }^{80}$ i.e. consistency in principle. According to him, compromise is more legitimate when officials are to take a decision among conflicting principles than it is in private situations. Whereas in the latter case it is understandable that individuals try to defend their conceptions of justice as much as possible, in the former case mutual accommodation matters more than individual conscience and compromises are the best way to ensure coherence among the different views represented in the law-making process or across the law as a whole. ${ }^{81}$

This argument does not hold, however. There are other ways than compromise to ensure coherence, both within each law or decision and across the law as a whole; provided one sees coherence as a virtue in a legal system, both forms of coherence may be realized by giving priority to a single principle or conception. Moreover, in the long run, less compromise will ensure more coherence across the law, as it is easier to cohere with past laws and decisions if they are not compromised than if they are. ${ }^{82}$ In the rest of the paper, therefore, the issue of the legitimacy of compromise will mostly be addressed separately from issues of coherence, even if the fourth argument I will use against internal compromise has been developed by some authors within the broader context of arguments in favour of or against coherence. ${ }^{83}$

In short, the general respect-based argument about the value of convergence and mutual accommodation of reasonable positions seems to cut both ways; it can justify compromise, but it can also lead away from it. Since I lack the space here to go into the details of other arguments for compromises of principles, I will not take position on their general justification. I will merely distinguish, among existing cases of compromise of principles, between those that can be tolerated and those that cannot, in order to argue more precisely against the latter in the

\footnotetext{
80 The terms 'integrity' and 'coherence' are used interchangeably in this paper. The former was first introduced by Dworkin, above $\mathrm{n} 1$, but has since then also been used and defended by Waldron, above $\mathrm{n} 71$.

81 See Waldron, above n 71 at 202.

82 See J. Raz, Ethics in the Public Domain (1995) at 312-13 on this point. See even Waldron, above n 71 at 194-5 for a similar contention.

83 Interestingly enough, some authors, like Dworkin, above n 1 at $79 \mathrm{ff}$. and Waldron, above n 71 at 202 seem to see external compromises as ways to ensure integrity or coherence, whereas others, like Raz, above n 82 at 312-13 invoke external compromises as counter-examples and arguments against coherence. All tend to agree, however, that the minimal principle of coherence within an individual statute or decision requires rejecting internal compromises: compare Raz, above n 82 at $314 \mathrm{ff}$. and Dworkin, above $\mathrm{n} 1$ at $79 \mathrm{ff}$. I will come back to this argument later in the paper.
} 
next section. It is useful in this respect to distinguish between the justification of two distinct types of compromise in case of principled disagreement: multiprinciple compromise and single-principle compromise.

\section{(ii) Multi-principle compromise}

Some moral conflicts derive from the opposition of two (or more) independent and competing principles that cannot all be satisfied on a particular occasion.

There are two ways in which such conflicts of principles may be settled through compromise. Both forms of compromise are external ones. First, the parties might come to a distributive compromise, that is the acceptance of one of the conflicting principles in one case and of the other principle in another case. Second, an integrative compromise, that weighs and ranks the principles by introducing principled exceptions to them, will often be the most desirable settlement of the conflict.

In terms of justification, if both parties endorse both principles, then it is easy to see that they will both be willing to compromise and agree on a ranking of the principles. If they do not endorse both principles, however, they may still recognize or acknowledge the opposed principle as a reasonable one to hold and see compromise as a desirable settlement. ${ }^{84}$ Thus, for example, let us imagine a person who opposes the death penalty whatever the degree of culpability while another thinks it is always right. The former may agree, however, to compromise and accept its restricted use according to the degree of culpability, provided the principles on the basis of which the latter proposes to establish the degree of culpability are deemed respectable by the former.

Of course, one problem when trying to reconcile conflicting independent principles is their potential inconsistency or incommensurability. ${ }^{85}$ Not all conflicts of value-laden principles, ${ }^{86}$ or value-principles, and their settlements face this difficulty, however, and it may be useful to distinguish two types of conflict. ${ }^{87}$

\footnotetext{
${ }^{84}$ See Dworkin, above $\mathrm{n} 1$ at $436 \mathrm{nn} 8$ and 9. Dworkin only refers to 'recognizing' a principle of justice without necessarily 'endorsing' it, but these statements imply a standard of reasonableness that conditions the recognition or acknowledgement of the principle as an independent principle that can justify a principled compromise. This point is similar to the one made by Waldron, above $\mathrm{n} 71$ at 204-8 who acknowledges the limits of integrity and of the willingness to compromise when some of the principles to accommodate strike one party as being particularly unjust and unreasonable. Waldron does not, however, stipulate 'thresholds of injustice beyond which integrity ceases to apply' and beyond which principles with which one disagrees become sufficiently unreasonable for compromise to become internal and undesirable.

${ }^{85} \mathrm{I}$ am hence assuming that not only values can be inconsistent and conflict, but also that they are sometimes incommensurable and that their conflicts cannot be settled in an objective or reasonable way. This is precisely where my account and Dworkin's diverge, since Dworkin's monistic conception of morality does accommodate neither conflicts of values and principles nor their incommensurability. See R. Dworkin, 'Do Liberal Values Conflict?' in Lilla, Dworkin and Silvers (eds), The Legacy of Isaiah Berlin (2001) 73.

${ }^{86}$ In this paper, I am dealing mostly with such value-laden principles. See N. MacCormick, 'Coherence in Legal Justification' in Peczenik et al. (eds), Theory of Legal Science (1984) 235 at 237 on the relationship between values and principles in this context: 'For any value, there is a principle according to which $\mathrm{V}$ either may be, or ought in the absence of countervailing considerations to be, or ought normally to be, or must in the absence of overriding considerations be, pursued or realised. Observance of principles is not an instrumental, but an intrinsic, means of realising values'.

87 See C. Larmore 'Political Liberalism' (1990) 18 Political Theory 339 at 350 for this distinction.
} 
The first case is where values themselves are logically inconsistent and cannot be compared or ranked mutually. ${ }^{88} \mathrm{~A}$ second form of value conflict arises when two generally mutually consistent values recommend rival courses of action, in some (but not all) circumstances, that cannot be performed at the same time. Whereas in the first case, the usual way out of disagreement is to reject one value for the other, the settlement of the second case does not necessarily require withdrawal from our commitment to one of the values but instead leads us to seek some ranking of them. In some cases, however, the weighing and the subsequent ranking of the values are impossible, or at least indeterminate given the lack of comparability of the values in conflict and more precisely the absence of a common metric. $^{89}$

It is important to keep in mind, however, that the verdict of inconsistency or incommensurability cannot be reached before the end of a substantive argument; it will only be issued when no compromise seems to satisfy any of the parties despite their mutual recognition of the conflicting principles. It might be objected that both parties may be wrong about consistency or commensurability of the principles with which they are willing to compromise their own principles, thus leading both parties to acquiesce in an erroneous theory. ${ }^{90}$ This is true, but the point is that we have no means of establishing the correctness and eligibility of a conception of a principle other than our own current views about its reasonableness and hence of telling others that they are wrong when they are about to compromise inconsistent or incommensurable values. ${ }^{91} \mathrm{We}$ can only do our best in determining what we think is the just result in each case while leaving open the possibility to improve our conceptions in future. ${ }^{92}$

It follows that my conclusion regarding the potential desirability of compromising over conflicting principles, recognized by both parties, does not hold if the principle with which one of them is asked to compromise is one she does not deem reasonable, independent, consistent or commensurable. For instance, one could imagine it were argued that one should compromise on the justice of imprisonment by granting bail to some detainees according to their eye colour

\footnotetext{
88 See T.M. Scanlon, What We Owe to Each Other (1998) at 358.

89 See Raz, above n 82 at 298, 317; R. Bellamy, Liberalism and Pluralism: Towards a Politics of Compromise (1999) ch 4 . Note that it is possible to strike a compromise among incommensurable values, but such a compromise cannot be objectively justified and is hence indeterminate morally. See Raz, above $\mathrm{n} 82$ at 316-17 on the justification of local coherence among weightings of incommensurable values once a compromise between these values has been struck in a certain way. On incommensurability, more generally, see J. Raz, The Morality of Freedom (1986) ch. 13.

90 See Rawls, above n 6 at 3: 'The only thing that permits us to acquiesce in an erroneous theory is the lack of a better one'.

${ }_{91}$ See B. Williams, 'Liberalism and Loss' in Lilla, Dworkin and Silvers (eds), The Legacy of Isaiah Berlin (2001) 91 at 101 .

2 I do not hold that we will necessarily converge or even individually get to the right answer after sufficient debate and critical reflection; epistemic limits and the burdens of judgement often prevent us from doing so. This fact does not prevent us from understanding each other, however, nor from communicating, contrary to what flows from the Wittgensteinian and dogmatic legacy of the necessary 'agreement in judgement' implied in 'understanding', nor does it make it a luxury to bother to engage in moral debate. All we need for the rational debate to seem worthwhile is to have a regulative ideal or hope of achieving rational consensus, rather than an unrealistic expectation that it will be achieved.
} 
or the day on which they were born. ${ }^{93}$ According to a distinction I mentioned earlier, such a compromise would amount to compromising a principle in an unprincipled way, i.e. internally, rather than externally. ${ }^{94}$ It is the least attractive kind of compromise over principles, for reasons I shall explain in the fourth section of this paper.

\section{(iii) Single-principle compromise}

By contrast to the first type of compromise of principles, the second form of compromise is not the product of a trade-off between independent principles, but it only involves a single principle. This occurs when a conception of this principle is affirmed by one group and rejected by another in favour of a different conception. Such conflicts can arise for two reasons.

First, both conceptions may represent two equally eligible aspects or conceptions of the same value-concept in the legal context ${ }^{95}$ which, sometimes or always, conflict with each other. I will call this first form of disagreement a case of metaphysical disagreement. One could consider the concept of equality as an example of a concept of which both equality of resources and equality of welfare might be equally eligible conceptions and appear reasonable to both parties, but do conflict with each other all the same. In this case, if we cannot reach a reasonable agreement, compromising might be as desirable as it was in the case of a conflict between two independent moral principles. Again, one may think of two forms of external compromise. On the one hand, the parties may agree to accept both conceptions of the principle, but in a distributive way. Thus, for instance, equality of resources may be recognized in one case, while equality of welfare is recognized in another. On the other hand, a more integrative form of compromise, that would rank both conceptions of the principle within the same principled scheme, could be found, provided of course both conceptions are not inconsistent. Thus, for instance, a principled scheme of equality may be established where equality of resources is given priority only as long as equality of welfare is guaranteed.

Most of the time, however, given our doubts about the eligibility of both conceptions, and our awareness that one of us might be wrong or that our conceptions might be inconsistent, we tend to abstain from compromising. Thus, a disagreement that may have legitimate metaphysical origins becomes temporarily epistemic. This temporary change of nature affects the prima facie desirability of compromise over a single principle.

\footnotetext{
93 This seems to be the gist of Dworkin's argument (above $\mathrm{n} 1$ at $436 \mathrm{n} 8$ and 9).

${ }^{94}$ See Dworkin, above $\mathrm{n} 1$ at 183 and 436.

95 This caveat is in order since the equal eligibility of the two conceptions of the same concept is not the result of a change of context so that two conceptions of equality, for instance, cannot be equally eligible in the legal context, but one of them could be so in the purely moral context. The reverse seems to be Dworkin's position about conflicting conceptions of the same concept than cannot compete with each other or contradict each other in the legal context, unless they are mistaken. This is due to Dworkin's views on conflicts of values and his faith in reaching as much coherence between our moral principles and values as possible through substantive moral argument. See Dworkin, above $\mathrm{n} 85$ at $86 \mathrm{ff}$.
} 
This is the second type of disagreement to oppose two conflicting conceptions of the same principle. In this case one of the two conceptions is mistaken but it is uncertain which one. ${ }^{96}$ This is the most frequent form of moral disagreement in pluralistic societies given the burdens of judgement and reason that prevail. It is also the form of single-principle disagreement over which it is most counterintuitive to compromise for reasons which I will develop in the fourth section of this paper. In a nutshell, such a compromise would be unprincipled and purely internal to the principle, to borrow the distinction I drew in the first section, thus integrating a mistaken conception with a correct one.

Before addressing the reasons why internal compromise about justice is not desirable, a brief caveat is in order. When two rival conceptions of the same concept are proposed, they often also refer to other background principles. Thus, for instance, imagine that I assert that killing a fetus is not murder by relying on the principle of the dignity of the mother. Although the principles of the personality of a fetus and of human dignity are independent principles, they are combined in this argument. Imagine a situation in which abortion is permissible up to a certain point in the course of pregnancy. It would be hard to tell in such a case whether what is being compromised are two independent principles or two conflicting conceptions of life. This is because all concepts are intertwined in a complex web of meaning. Most legal cases where the application of a concept is limited by further constraints are not therefore necessarily internal compromises which combine a number of conceptions of the same concept. Rather, they may be cases where independent considerations embodied within a more complex legislative objective limit the application of a concept. ${ }^{97}$

\section{The Limitations of Compromise}

Internal compromises stricto sensu combine either two conflicting but unequally eligible or inconsistent conceptions of the same principle, or the content of a single principle with another non-independent, unreasonable or inconsistent principle.

There are many reasons why we should abstain from making such compromises. Of course, these reasons do not exclude the possibility that people will prefer to coordinate on an internally compromised solution rather than on none at all. ${ }^{98}$ Four arguments will now be advanced against such internal compromises.

\footnotetext{
96 The fact of disagreement does not imply that there is no objective truth and fact of the matter in the moral realm; such an assertion would call for a meta-ethical argument I am not prepared and do not need to make here. Moral pluralism can have objective grounds and epistemic disagreement may be the result of the numerous burdens of judgement which plague human reasoning. If there were no fact of the matter, disagreement and the belief that there is some truth to argue about could also be the result of the false realism that flows from the common use of moral language. The point is that important epistemic barriers and lack of agreement on how to get over them prevent us from establishing both the truth of moral judgements and a methodology for doing so in a universally acceptable way.

${ }_{98}$ See Cohen, above $\mathrm{n} 6$ at 314 for the distinction between a compromise of justice and a simple restriction of it.

98 See Dworkin, above $\mathrm{n} 1$ at 180 . See also Habermas, above n 20 at 204.
} 
Taken separately, each of these arguments has a limited scope, but all four must be understood in such a way as to support and complement each other. ${ }^{99}$

\section{A. Inefficiency}

An argument sometimes made against internal compromise reflects its lack of workability or inefficiency. This argument has been advanced most famously by Dworkin. ${ }^{100}$

As an example of inefficient internal compromise, one could imagine a case where, in order to strike a compromise between people who think a fetus is a person and those who hold the contrary, the statute enacted says that a fetus is half a person and that accordingly only half of the respect due to human life is owed to it. Such a statute would not only be unintelligible, but completely unworkable: it would be impossible to deduce substantive answers to legal problems from it.

However, most cases of internal compromise we can imagine, such as the permissibility of abortion for women with blue eyes only, for instance, are not actually impractical or unworkable. So, our intuition and the more general case against internal compromise must be founded on another broader argument that would establish why it is wrong for the parties to accept such a compromise in other cases too.

\section{B. Potential Injustice}

A second argument against internal compromise is that it seems an inappropriate response to cases where disagreement has epistemological origins. ${ }^{101}$ This, as we have just seen, is true of most disagreements in pluralistic societies.

When people disagree about what justice is, they have strong views and opinions about what ought to be done. A compromise that gives something to each of the parties may well look to them as if it is leading them away from the right answer. $^{102}$ Compromising on justice may even mean being unfaithful to what

\footnotetext{
99 This is also Dworkin's way of arguing against internal compromise, through a crescendo of different arguments which are all limited in their scope until the value of integrity is postulated. The difference with Dworkin's account of checkerboard statutes, however, is that my first three arguments hold and that integrity is not simply postulated at the end, but justified on its own before it is used as a fourth argument against internal compromise. In his account of checkerboard statutes, Dworkin, above n 1 at $79 \mathrm{ff}$. is not arguing primarily against internal compromise but for integrity, whereas I am interested here primarily in internal compromise and only instrumentally in integrity.

100 Dworkin, above $\mathrm{n} 1$ at 182.

101 Given what I said earlier about false realism, I assume here that most people will think they are arguing about some common truth to which they have a limited access that is, with value pluralism, the cause of most of our disagreements. Besides, even if some of us are conscious relativists, it is sufficient for this second argument to work that one of the parties in the dispute be not.

102 Gaus, above n 45 at 184. It is important not to confuse this argument based on each party's concrete perspective about justice with a collective and more abstract argument based on the justice of such internal compromises in general, that I regard as doomed because of reasonable disagreement about justice, as I explained before. See on the opposition between concrete arguments of justice of outcome against internal compromises and the difficulty to make a more general argument of justice against them, Dworkin, above n 1 at 180 .
} 
they believe to be the true meaning of the concept of justice ${ }^{103}$ and this justifies preferring some other solution to the internally compromised one. Deferring to a view one regards as wrong or at least unreasonable, either entirely or in a compromised way, amounts to taking a complete moral stance. Indeed, we should act only for reasons we believe to justify our action, i.e. only if we think that the action is justified. Since we hold our own views on the question not merely because they are ours, but because we believe them to be true, deferring to the other party's view we regard as wrong or unreasonable cannot be justified in the same way. The only justification for deferring or compromising would then be, according to Joseph Raz, to give other people's views a weight that we do not give our own. ${ }^{104}$ This explains why deferring to, or, worse, compromising with other views, in case of epistemic disagreement, is such a difficult thing to do.

Furthermore, such a compromise might not look like a 'compromise' to the parties, since it does not provide them with any sort of positive repercussion at all. ${ }^{105}$ An example may help to clarify the problem. ${ }^{106}$ Suppose half the people in a community hold the opinion 'to each according to his need' and the other half 'to each according to his work'. Each finds the other half's conception of the principle of distributive justice reasonably unacceptable; eventually they compromise on 'to each according to his work, unless his work does not suffice to meet his most basic needs: then we keep him afloat with transfer payments'. The compromised principle may very well look wrong to all the parties, since it contradicts and violates their conceptions of distributive justice and hence does not strike them as a positive outcome.

Two counter-arguments have been put forward against this conscience-based critique of internal compromise in politics.

The first one is that people should sometimes compromise on a position that both sides think is wrong in order to reduce the magnitude of potential moral error or injustice in one direction or the other. Thus, one may contend that, in everyday politics, internal compromise will prevent instances of injustice that would otherwise occur. According to Dworkin, for instance, 'we cannot say that justice requires not eliminating any injustice unless we can eliminate all' ${ }^{107} \mathrm{It}$ seems indeed, to borrow Rawls' words, that 'an injustice is tolerable when it is necessary to avoid an even greater injustice'. ${ }^{108}$ Although this argument is appealing, it is too limited in its scope. ${ }^{109}$

\footnotetext{
103 See Dworkin, above n 1 at 180: 'Both [parties] have a reason of justice for preferring some other solution to the checkerboard one'. See also Dworkin, above n 1 at 182: 'I would rank the checkerboard solution not intermediate between the other two but third, below both, and so would many people'. See Halowell, above n 13 at 173 : 'Compromise, as a self-sufficient principle divorced from all considerations of truth and justice, is simply, in the last analysis, the ancient Trasymachian doctrine that might makes right'.

104 See J. Raz 'Disagreement in Politics', 43 American fournal of furisprudence 25 at 27-8 (1998).

105 I owe this point to John Gardner.

106 This example is adapted from an example given by Luban, above n 23 at 415 .

107 Dworkin, above $\mathrm{n} 1$ at 181 .

108 Rawls, above $\mathrm{n} 6$ at 3.

109 See Wertheimer, above $\mathrm{n} 7$ at 175 .
} 
The first problem with it is that it is based on divisible cases of justice or injustice. Let us imagine, for instance, the number of death-row prisoners we could save if a compromise was struck where all blue-eyed detainees be liberated. Many claims based on principles of justice are not divisible in this sense, however. For instance, if the same disagreement applies to the liberation of one single prisoner, it is difficult to see how the injustice committed could be divided and hence reduced.

Additionally, even if reducing the number of injustices in divisible cases of justice can be a legitimate end for a moral compromise, the means to that effect may still be unjustifiable with respect to the parties' other views on justice. ${ }^{110}$ Thus, for instance, pro-life advocates might be willing to accept that pro-choice advocates will not give up legalization of abortion, but insist that they give up policies that would increase the number of abortions, such as policies of subsidized abortion. Pro-life advocates might agree on such a compromise to save some lives, while pro-choice advocates might agree on such a compromise to save pregnant women's autonomy of choice. However, the refusal to fund abortion, when childbirth is funded, creates an almost irresistible pressure on indigent women to carry a child to term; in this sense, such a compromise might be said to violate the basic rights of poor women to choose between giving birth and having an abortion. Therefore, although it is possible to think of compromises which would reduce the number of abortions while respecting women's autonomy, this second limitation to the argument makes the moral desirability of internal compromises appear even more limited.

Let us go further and imagine that advocates of affirmative action measures accept as a compromise that list-quotas of women in political elections be set at $25 \%$ rather than $50 \%$ of the candidates. The aim of this compromise is prima facie justifiable in the sense that more women might become eligible than without any quotas at all, while reducing the restrictions of the electoral freedom implied by quotas. One may wonder, however, whether there is not more injustice in potentially limiting the eligibility of men and women by half in a way that is not representative at all of their proportion in the population, than in leaving it to the political process to decide. Such artificial guidelines might in fact have more pernicious consequences for material equality between men and women than it seems at first sight; equality is equality after all and there might be no way to compromise it in one instance without jeopardizing the entire gender balance in society.

Finally, let us suppose that some people who believe very strongly that abortion is murder accept a compromised abortion statute, stating that abortion is allowed on Fridays only, on the basis that it allows for fewer murders than a fully permissive statute. It remains the case, however, that they will rank internal

\footnotetext{
110 See Gutmann and Thompson, above $\mathrm{n} 7$ at $88 \mathrm{ff}$. See also D. Réaume 'Is Integrity a Virtue? Dworkin's Theory of Legal Obligation', 39 University of Toronto Law fournal 380 at 397 (1989).
} 
compromises last in other circumstances where the substantive issue is less grave. Imagine, for instance, the case in which it is smoking marijuana that is allowed on Fridays only; conceding to this on Fridays clearly does not have the same weight and moral appeal for those who want to ban all drugs as the equivalent in the abortion case. ${ }^{111}$ This suggests that people still share an intuition against internal compromise. ${ }^{112}$

A second counter-argument against the conscience-based argument defended here has been elaborated by Dworkin himself. He objects that the argument that no individual should vote or take a decision against her conscience does not hold and even begs the question. ${ }^{13} \mathrm{He}$ does acknowledge that a legislator who votes against her own conviction behaves irresponsibly according to her own standards, but thinks that the argument does not explain why we should reject internal compromise as a general outcome. He imagines a mechanical legislative structure which would produce compromised statutes without asking any member of the legislature to vote for them as such, for it would result in proportioning the content of any decision according to the number of votes.

As a reply, however, one could contend that by consciously participating in such a mechanical exercise and thus by agreeing to it, members of the legislature are already acting against their conscience.

\section{Concept Attribution}

Whereas the second argument was based on the parties' point of view, there is a third argument to be made against internal compromise from a more abstract point of view. This argument is intrinsically related to the question of concept attribution, to borrow Nicos Stavropoulos' term. ${ }^{114}$ Concept attribution is shorthand for the determination of the concept of which people hold conceptions.

When internal compromises try to reconcile true and false conceptions of the same concept, ${ }^{115}$ conceptions which are equally eligible, but inconsistent, or nonindependent or inconsistent concepts with independent or consistent ones, they produce so-called 'gerrymandered ${ }^{116}$ concepts. ${ }^{117}$ Such concepts are not intelligible per se and do not stand on their own. Internal qualifications of the same

\footnotetext{
111 I thank Thomas Pogge for this example and a useful discussion on checkerboard statutes.

112 Maybe what this suggests is that when grave matters of life and death are at stake, people tend to decide independently of their other moral principles and especially their ethical intuitions against internal compromise and the injustice it entails.

${ }_{113}$ Dworkin, above $\mathrm{n} 1$ at 182.

114 See N. Stavropoulos, Objectivity in Law (1996) at $186 \mathrm{ff}$. who seems, however, to restrict the issue to concept attribution in adjudication. I think that it follows from his reasoning about which concepts can be attributed in adjudication that not all concepts can be compromised in a non-principled way in the legislative process in the first place; if the contrary were true, this would make adjudication an even more difficult exercise.

5 See, for instance, Kuflik, above n 11 at 51 for an argument in favour of a morally acceptable compromise between 'claims based on moral convictions that one can now perceive to have been mistaken'.

116 The term 'gerrymandering' refers, in politics, to the rearrangement of voting districts so as to favour the party in power. The origin of the term was in such an arrangement made by the Massachusetts Jeffersonians when Elbridge Gerry was governor.

117 See Stavropoulos, above n 114 at 190.
} 
concept or principle can even amount in some cases to contradicting the original principle itself. ${ }^{118}$

There are different reasons why concept-gerrymandering should be avoided. First, concepts cannot be created ad hoc depending on the needs of interpretation. A definite number of concepts are at our disposal and what varies are the conceptions and applications of these concepts. The contrary would indeed seem absurd to each of us given that meaning has logical priority over compromising. Second, concepts relate to each other in a complex way; this imposes a requirement that any conception of a concept must fit uses of that concept that are related to other concepts and their respective conceptions. ${ }^{119}$ This is precisely something an internally compromised concept could no longer do. Finally, we can make a virtue of this necessity: a logical consequence of the fact that our concepts are already given does indeed correspond to the need for some minimal level of determinacy and predictability in the law.

Of course, one may object that there are more complicated concepts that we could name conciliatory or umbrella concepts, under which conflicting but commensurable conceptions can co-exist when cases of single-principle disagreement have metaphysical causes. ${ }^{120}$ One could consider the concept of equality as an example of a concept of which both equality of resources and equality of welfare could be equally eligible conceptions and look reasonable to both parties. If the existence of such genuinely complex concepts could be established, there would be no a priori reason for favouring the epistemic interpretation of single-principle disagreement over the metaphysical one, as we saw in the previous section, and, in fact, all conflicting conceptions could be retained. Such conceptions could therefore also be the object of an external and principled compromise within the same idea, where both parties accept them as reasonable and commensurable conceptions, without incurring a contradiction of the original principle. ${ }^{121}$ For example, the parties could accept a compromise within the principle of equality between the two conceptions of equality of welfare and equality of resources on the following terms: 'To each according to her work, unless the extent of her needs falls below a certain threshold'.

Such concepts exist, at least on the face of the evidence we have. However, to establish their existence requires a substantive argument. Now it is true that both parties may be wrong and that it just so happens that a prima facie internally compromised view has not yet been defended as a coherent conception of the concept of justice, but could well be reasonably held in the future as an eligible conception of a complex concept of justice. This is a contingent matter, however. There are some good reasons, on the one hand, why we should not make one particular view, which is not yet reasonably defended and intelligible as

\footnotetext{
118 See R. Dworkin, Sovereign Virtue, The Theory and Practice of Equality (2000) at $49 \mathrm{ff}$.

119 See Stavropoulos, above n 114 at 197.

120 Ibid at $195 \mathrm{ff}$.

121 Contra Dworkin, above n 118 at $49 \mathrm{ff}$.
} 
such in the community, the community's view and, on the other, why we should not compromise two conceptions one of which may be right and the other wrong. The reverse may also be true. A gerrymandered concept may mistakenly appear intelligible and coherent to reasonable people. ${ }^{122}$ In cases of epistemic indeterminacy, however, people have no other solution but to trust their conceptions of a normative concept and disagree about it or even converge on an internally compromised conception of it as long as they regard it as principled and provided the conditions for further deliberation and progress on the matter are guaranteed.

An objection that is frequently raised against this external and abstract view of concept attribution is that, by condemning internal compromise, it constrains legislative authority and its autonomy to draft bad or gerrymandered laws if it so wishes. This objection is misconceived.

First, given our awareness of our fallibility and our difficulty in reaching reasonable agreement on matters of justice, the response we should give to disagreement ought to reflect cautiousness despite autonomy. We should not act so as to prevent a better answer coming out later in the debate. It follows that we should not prefer pushing forward our views of justice, for instance through internal compromises, to reaching other settlements that correspond better to the community's view as a whole; ${ }^{123}$ the community's view can never be equated with a compromised view nobody could defend as such in the community or that would amount to a partitioning of justice. ${ }^{124}$

Second, the objection's fear of a complete identification of law with ethically correct views is misplaced: the content of the law is constrained by past conceptions of its concepts in ways that our ethical views are not. ${ }^{125}$ This is one of the reasons why external compromises are so frequent in politics; they provide the means to reconcile past decisions with new and more appropriate ones and hence to ensure continuity in change in the political community. This is not, however, a reason to accept internal compromises, as they would jeopardize continuity and coherence not only within each law or decision, but within the law as a whole.

\section{Political Integrity}

One last argument against internal compromise is based on the violation of one of the political ideals the state ought to respect when enacting laws. According to this argument, internal compromise fails to capture the core of our sense of the political virtue of consistency in principle, that is also referred to as coherence or integrity. This argument of public morality should be read in contrast to some of the prior arguments that were based merely on officials' individual perspectives of justice.

\footnotetext{
122 I thank Leslie Green for this suggestion.

123 See Dworkin, above $\mathrm{n} 1$ at 211 and 213.

124 See Snyder's response to Coons, above n 5 at 804 .

125 See Stavropoulos, above n 114 at 187-8.
} 
The argument of political integrity refers to the duty for the state to act as consistently as we would in our own individual actions. ${ }^{126}$ Even when legislation is the product of a compromise, it should express a coherent conception of justice; a person regards a law as coherent, even though she may disagree with it, only if she can plausibly imagine the view it expresses as being held by herself. If a middle-ground view between either two incompatible conceptions of the same principle or two incompatible principles is not something we would act on individually, then it cannot be a desirable way for the political community to act as a whole and hence for public officials to decide.

The principle of integrity has been developed most famously by Dworkin. According to him, integrity calls for as much coherence as possible in the lawmaking process, on the one hand, within the law as it stands and, on the other, between past and new law. We need not, however, accept Dworkin's conception of moral and legal coherence in the law as a whole to be sensitive to his argument about coherence in the law-making process. ${ }^{127}$ First of all, the conception of integrity used here is limited to local and synchronic coherence as opposed to general and diachronic coherence. As such it only encompasses consistency in principle within a single law or decision rather than general coherence across the law as a whole. ${ }^{128}$ Second, Dworkin postulates, rather than argues for integrity; he uses our intuition against internal compromise to justify the need to postulate the principle of integrity. ${ }^{129}$ Here, by contrast, I am using a justified principle of integrity to argue against internal compromise. This explains how it is possible to use some of Dworkin's intuitions about integrity without having to accept the rest of his argument on associative obligations and loyalty to the community. But it also clarifies why it is necessary to provide a brief sketch of an independent justification of the principle of integrity before it can be used to argue against internal compromise. This justification does not aim at being complete and only supports local and synchronic coherence, as it is the minimal form of coherence needed to show that internal compromise is morally undesirable in politics and in the law-making process.

Political integrity may be justified in its local and synchronic application to the law, because we see ourselves as the authors of the political decisions made by our governments; for that purpose, we require the state to respect integrity because a citizen cannot consider herself as the author of rules that are inconsistent in

\footnotetext{
126 Dworkin, above $\mathrm{n} 1$ at $183-4$.

127 Dworkin, above $\mathrm{n} 1$ at $188-9$ himself contends that his argument is not the only one for integrity. See also Waldron, above $\mathrm{n} 71$ at 191 .

${ }^{128}$ Of course, the distinction is not always that clear in practice: diachronic coherence has to be ensured synchronically too and synchronic coherence often reconciles diachronic elements.

129 On Dworkin's postulates, see Dworkin, above n 1 at 183 and G. Rey, 'A priori conceptions' in S. Villanueva (ed.), Concepts, Philosophical Issues 98 at 101-2 (1998). Note that the hypothetical nature of Dworkin's conception of integrity explains the apparent circularity there is in his account between justifying integrity in terms of political obligation, on the one hand, and justifying political obligation in terms of integrity, on the other. Once the justificatory nature of Dworkin's conception of law is made apparent, however, it is clear that integrity need not be justified, but only postulated for Dworkin's purposes.
} 
principle. ${ }^{130}$ Moreover, such rules cannot match pre-existing individual reasons, that tend to be coherent overall, and cannot therefore enable us to abide by those reasons better than on our own. ${ }^{131}$ Then they cannot claim authority along the lines of Raz's widely accepted account of legal authority. In his account, the law must be capable of claiming authority. As such, it must be able to claim that, at least in some cases, the alleged subject is likely to comply with reasons which apply to her better if she accepts the directives of the alleged authority as authoritatively binding and tries to follow them, than if she tries to follow the reasons which apply to her directly. ${ }^{132}$ Finally, synchronic coherence may also be justified on grounds of respect for others' reasonable, albeit diverging, conceptions of what the particular law should be in our community. ${ }^{133}$

Of course, one may argue that in some exceptional cases internal compromises of principle might have to be struck within the same legal principle, and that, in these cases, integrity or any other ideal invoked against them may have to be sacrificed to concerns of justice or fairness. Dworkin himself refers to the exceptional possibility of sacrificing integrity, both within each law and within the law as a whole, to justice or fairness generally. ${ }^{134}$

Dworkin adds, however, that 'checkerboard statutes are a flagrant and easily avoidable violation of integrity'. This indicates that he does not see internal compromises within each law as a desirable sacrifice of integrity to justice or fairness in contrast with some forms of diachronic incoherence. Besides, integrity is a principle that only applies in circumstances of reasonable disagreement over justice (so-called 'circumstances of integrity' ${ }^{\text {'35}}$ ); it is therefore both independent and relative to the principle of justice, as it is meant to guide political decisions about justice when the latter is contested and cannot guide them itself. As such, it is difficult to see how integrity could be sacrificed to justice, when the different conceptions of the latter, that are at stake before the compromise, are themselves

\footnotetext{
${ }^{130}$ For a mention of this argument, see Dworkin, above $\mathrm{n} 1$ at 189 . As to the question of why there is a natural individual tendency to consistency in principle, I simply refer the reader to the following logical proof: 1) p or not-p, 2) $p, 3) p$ or q, 4) not p, 5) q. Note that I am not arguing that individuals do not believe in conflicting principles nor that they do not compromise such independent principles in practice, but only that most of them intuitively reject internal compromises. On the origins of the axiom of contradiction in Occidental ethics, see Plato, Gorgias (1990) at 482: 'Since I am one, it is better for me to disagree with the whole world than to be in disagreement with myself'.

${ }_{131}$ Note that I take values and reasons to be intrinsically related here; with the exception of rare hypotheses, in which it is a person's personality or her ambitions that dictate her moral behaviour, her reasons for acting in a way and not the other are usually related to the value of this action. See J. Raz, 'Mixing Values' in Engaging Reason, On the Theory of Value and Action (2001) at 182-3 n 3 and at 196. In this context, therefore, if the values of an action and the principles they support are gerrymandered at law, then the legal reasons for that action will be too, thus jeopardizing two of the conditions of the Razian conception of authority: the relation of dependence between legal reasons and personal reasons, on the one hand, and the normal justification thesis, on the other.

${ }_{132}$ Raz, above n 82 at 198; Raz, above n 89 at 53. Note that Raz, above n 82 at 298-301 argues that his conception of authority defeats the argument of general coherence in the law; the point here, however, is a point about what Raz calls local coherence rather than general coherence and he admits at 314-19 that local coherence matters in some cases and that, in these cases, internal compromises cannot be regarded as desirable.

${ }^{133}$ See in particular Waldron, above $\mathrm{n} 71$ at 202. As we saw before, both coherence and respect may or may not justify striking external compromises depending on the circumstances. However, they may justify a contrario refusing to strike internal compromises with unreasonable conceptions of justice.

${ }_{134}$ See Dworkin, above $\mathrm{n} 1$ at 217.

135 See Waldron, above n 71 at $189 \mathrm{ff}$.
} 
contested. Finally, even if this was granted, it is difficult to see how justice could call for an internal compromise of its own principles and thus constrain the application of the principle of political integrity within the same law, since integrity is precisely meant to avoid such contradictions within the concept of justice itself. It seems therefore that, within the same law, the principles of justice and integrity can only very rarely pull in different directions. ${ }^{136}$

Dworkin's other contentions about the balance that ought to be struck and the compromises that ought to be made between the demands of justice and fairness, ${ }^{137}$ or of justice and integrity, can easily be reconciled with his rejection of internal compromises. The compromises he has in mind there are external compromises between either independent principles or a judge's second-order beliefs about which principles of justice or integrity to follow, rather than compromises on the content of the first-order principles over which she has to take a decision. It could mean that either justice or integrity is to prevail, or that a bit of both should, depending on the circumstances. It does not, however, necessarily mean that the outcome of this first-order compromise, if there is one, will be an internally compromised one where a new conception of justice is compromised with wrong or inconsistent conceptions expressed in deliberations or encompassed in precedents. There are smoother ways to ensure a transition when a position has won a sufficient majority than compromising principles internally; one may think of an external compromise where a new government combines creating new laws it sees as being more just with retaining some of the past government's laws for a while. ${ }^{138}$ As Dworkin argues, politics

is a theatre of debate about which principles the community should adopt as a system, which view it should take of justice, fairness and due process, not the different story [...] in which each person tries to plant the flag of his convictions over as large a domain of power or rules as possible. ${ }^{139}$

This is also what Raz means when he discusses the 'partial reform dilemma'; this dilemma is set between, on the one hand, the coherence of purpose of the law as a whole and, on the other, the pursuit of the morally correct line. It results from the impossibility for judges and sometimes for legislators to entirely reform past

\footnotetext{
136 This does not mean, however, that the principle of integrity is dependent on the principle of justice, contrary to what Réaume, above n 110 at 392 ff claims. The critique might hold with respect to Dworkin's negative postulation of integrity, but not to the argument made in this paper. To be independent of justice, integrity need not be conflicting with it. To take an example, it is not because justice and fairness condemn plural voting that fairness is not an independent principle and cannot provide an independent justification against plural voting. Moreover, there can be instances in which coherence may require something our conceptions of justice would have us reject; this is the case with diachronic coherence, for instance, as consistency with the conceptions of justice entrenched in past laws may contradict our current conceptions.

137 See Dworkin, above n 1 at 249-50, 256, 340.

138 See J. Waldron "“Transcendental Nonsense" and System in the Law', 100 Columbia Law Review 16 at 42 (2000). See also Dworkin, above $\mathrm{n} 1$ at 218.

139 Dworkin, above n 1 at 211 (emphasis added).
} 
law in order to produce the new scheme that they would like to enact. In such a case, officials have to decide

whether compromising and choosing the morally second-best rule which has better consequences is best in the circumstances, or whether it is more important to let the law speak clearly and soundly on a moral issue, and hope that an occasion to extend the correct ruling to other cases will arise and be followed before long. ${ }^{140}$

Raz then seems to be saying that the second horn in this dilemma should be chosen, thus undermining the legitimacy of internal compromise. ${ }^{141}$

For many people, as it transpires from this example, the response to reasonable disagreement and the solution to the occasional need to converge peacefully lies in a commitment to democracy as a procedural means for resolving conflicts within a given community. This is particularly the case when deliberation and mutual accommodation have proved unsuccessful and when compromises on the outcome have not been reached informally ${ }^{142}$ or are not desirable. Interestingly enough, discussions about compromise of principle very often regard democracy as the paradigm of political compromise and it is to this question that I will turn now.

\section{Democracy as a Fair Compromise}

In his General Theory of Law and State, Hans Kelsen contends that 'compromise is part of democracy's very nature'. ${ }^{143}$ It seems therefore that commitment to democracy itself can be understood as a compromise, rather than as a mere 'compromise technique' in the cases where it achieves compromises qua outcome. In this sense, democracy may be said to amount to a compromise qua process.

As we saw in the first section, a compromise qua process is a certain way of achieving conflict resolution by a procedure of 'give and take', whatever the actual terms of the final settlement might be. This form of compromise is instantiated by the case where the parties submit their dispute to the determination of a certain decision-making procedure. Compromises qua process can take the form of democratic deliberation in which each point of view must be given a voice in the process of deliberation and each participant given equal voting rights, but where the parties accept that the final collective decision will be the majority's, except in special cases where unanimity is required. This procedure amounts to a

\footnotetext{
${ }^{140}$ Raz, above $\mathrm{n} 82$ at $316-17$.

141 Raz, above $\mathrm{n} 82$ at 317.

142 In fact, even when external compromises are reached informally on matters of principle, for instance by trading support for some principle in exchange of future support for another one, they take place in an official arena, be it the legislature or the judiciary, where settlement procedures are omnipresent, and they are therefore oriented towards a vote; for instance, what is usually traded are votes and even when people have reached the perfect compromise where they have gained sufficient majority or even unanimity on each project respectively, procedure will often end by taking a vote.

${ }^{143}$ H. Kelsen, General Theory of Law and State (1961) at 288.
} 
compromise even if all agree to it, for each individual can presumably expect to be outvoted some of the time and thus to see a different view of justice from hers adopted. In effect, the procedure is one of compromise by succession: individuals take turns in getting their own way on issues instead of compromising on each particular one. ${ }^{144}$ It assumes, however, that there will be no permanent minority whose views are consistently overridden by the majority and that basic minority and democratic participation rights are respected.

Even when majority decision is understood as a compromise, it does not necessarily require or lead to further compromises qua outcome on the particular issues at stake. It is important to keep this distinction in mind as it helps to see why democracy should not be regarded as the necessary paradigm of all compromises and in particular of compromises qua outcome.

Of course, the mere fact that a democratic decision-making procedure may produce decisions that one of the parties would oppose, coupled with the possibility of getting her views through on another occasion thanks to vote trading, will often suffice to allow us to understand such decisions as external distributive compromises about justice. In fact, Dworkin's contentions about external compromise qua outcome emphasize its relationship with democratic procedures; in such procedures, he says, 'each point of view must be allowed a voice in the process of deliberation but the collective decision must nevertheless aim to settle on some coherent principle whose influence then extends to the natural limits of its authority'. ${ }^{145}$

Moreover, the process of constitution of a majority on some issue, which will enact its own view of justice, is often subject itself to the need to make integrative compromises; in most cases, there is a broad range of opinions on moral issues and it is rare that any single opinion will command a majority from the start. Instead majorities are very often coalitions of people with different and sometimes conflicting views, who have all made concessions to be in the majority. However, this simple fact is not conclusive.

First, the fact that logrolling is a current practice does not lead to the conclusion that a compromise qua outcome is morally desirable. It might be regarded as morally worse that people join a majority by consenting to compromises qua outcome rather than by being persuaded to endorse the quasi-majority's view of justice.

Second, people may indeed trade votes and make different concessions, but these do not necessarily have to be related to the actual content of the final, single view of the majority. Votes for a specific law could be traded against other advantages or future votes rather than for concessions in the particular content of the voted law. Imagine, for instance, that someone in the minority on a taxation issue trades her votes on a social benefits question and thus sacrifices her opinion on a less important issue for support over a more crucial one.

144 Carens, above n 10 at 134 .

145 Dworkin, above n 1 at 179. 
Finally, the contention that in a democracy people should make concessions to their opponents, even when the concessions are not needed to create a majority, ${ }^{146}$ is misleading. True, there is an increasing need nowadays for more inclusive politics based on mutual acceptance and respect in the face of the reasonable nature of disagreement and our mutual fallibility. ${ }^{147}$ There is a difference, however, between, on the one hand, the guarantee of respect and equal chances in deliberation or the willingness to listen and maybe to be persuaded and, on the other, the actual constitution of the chosen scheme of justice that risks losing its true nature if it is internally compromised. The acceptance of the majority rule, i.e. the conclusion of a compromise qua process, shows sufficient respect for the reasonableness of the positions at stake, including the minority's stance when its turn comes. ${ }^{148}$ Besides, such a conception would replace majority rule with artificial convergence, thus simultaneously undermining political equality that is part of the basic justification for democratic resolutions of disagreements.

A problem for any argument in favour of compromise qua process is that reasonable disagreement over the legitimacy, justice and fairness of a substantive issue also applies to the dispute-settlement procedure. A solid argument for the majority rule, be it in terms of compromise or not, needs therefore to be founded on something other than its justice or fairness, since it is precisely because of disagreement about justice and fairness that people will choose the majority rule as a way to reach a settlement and converge on a single line of action. ${ }^{149}$ Such a higher-order principle of justification may be founded on the need to solve co-ordination problems and to converge on a single political rule of action, for instance; the fairest way of doing so could in particular be the majority-rule as it gives maximal decisiveness to all citizens, its fairness being based on an impoverished sense of the principle of political equality. More historical and pragmatic explanations may also be used to avoid an escalation of reasonable moral disagreement from substance to procedure. ${ }^{150}$

There is therefore some perceptiveness in Singer's contention that democracy and the majority rule are 'paradigms of a fair compromise'. ${ }^{151}$ By this, Singer means that, in circumstances of reasonable disagreement, the equal division of power and the use of the majority rule to reach a decision among equal votes could be seen as the paradigm of a fair compromise. Fairness is understood here in terms of compromise rather than in absolute terms that would imply full objective knowledge of what is just and fair on the part of both parties, ${ }^{152}$ or at

\footnotetext{
146 See Cohen, above n 12 at 47; Carens, above n 10 at 135.

147 See W. Galston 'Democracy and value pluralism' (2000) Social Philosophy and Policy 255 at 267-8.

148 See Waldron, above $\mathrm{n} 71$ at 165 on the majority rule as a respectful procedure. On this point, see also Singer, above $\mathrm{n} 10$ at $32 \mathrm{ff}$.

149 See for a similar argument, Dworkin, above n 1 at 180.

150 See also R. Nozick, Anarchy, State and Utopia (1974) at 98 on the pervasiveness of disagreement: 'When sincere and good persons differ, we are prone to think they must accept some procedure to decide their differences, some procedure they both agree to be reliable or fair. [But] . . . this disagreement may extend all the way up the ladder of procedures'.

${ }_{151}$ Singer, above n 10 at 32. See also Carens, above n 10 at 134.

152 Singer, above n 10 at 33-4.
} 
least a rationally demonstrable proof of what is just and fair. In these circumstances, 'fairness as a compromise is all that can be expected because, as we have seen, it is extraordinarily difficult to decide-let alone reach agreement on-what is a sufficient reason for an unequal distribution of power'. ${ }^{153}$ According to Singer, furthermore, what makes majority rule fairer 'as a compromise' and provides a stronger reason to respect it is that what is asked in return for the acceptance of the compromise qua procedure is a minimal sacrifice on the part of each party who is given equal weight in the procedure. ${ }^{154}$ This very idea of minimal sacrifice and maximal decisiveness ${ }^{155}$ in democratic procedures is what leads Kelsen to contend that it is precisely because of this tendency towards compromise that democracy is an approximation to the ideal of complete self-determination'. ${ }^{156}$

\section{Conclusion}

We should now be able to propose an answer to the puzzle we started with: in circumstances of persistent reasonable disagreement about justice, may we compromise about justice in the law?

The response is as ambiguous as the concept of compromise itself: yes, we may in most cases, although compromising is only one of the many ways in which we can accommodate our mutual differences and settle our reasonable disagreements. In some cases, moreover, it is clearly not desirable at all. Following our initial intuition, we can see that internal compromise in case of disagreement over principles of justice constitutes, at the most, a second best alternative. Although it is better than no convergence at all, it fails to capture, among other things, the core of our sense of law's intelligibility and workability, of justice, of correct concept attribution and, finally, of political consistency.

This conclusion does not, however, hold for all political compromises in case of conflicts of principles. It does not apply, for instance, to the conflicts which oppose two or more independent moral principles provided their conceptions are reasonable, independent and consistent. The same is true of conflicts which oppose two conceptions of the same principle if, by the end of a substantive argument, both parties hold that the two conceptions reflect two conflicting but commensurable values that are equally constitutive of the same concept. All these compromises of principles are external ones; they are merely compromises about which scheme of justice we should adopt, whether they are distributive or integrative.

\footnotetext{
153 Ibid at 35-6.

154 Ibid at 32, 36. See also Kuflik, above n 11 at 299.

155 See on this minimally controversial defence of the principle of majority rule, Waldron, above n 71 at 114 ; B. Ackerman, Social fustice in the Liberal State (1980) at 283.

156 Kelsen, above n 143 at 288.
} 
As an alternative to external compromise qua outcome in settling political disagreements, I suggested compromise qua process, as exemplified by democratic procedures and the majority rule. Such compromises select one of the views reasonably held during deliberation where all views have had the chance to be represented and discussed. Accepting the majority rule qua compromise does not necessarily imply striking further external or internal compromises qua outcome within the majority's decision; such concessions may be made in the course of the democratic process, but they are not a pre-requisite nor a necessary consequence. The contrary would transform majority rule into artificial convergence, thus undermining at the same time the political equality that is part of the basic justification for the democratic resolution of disagreements. Majority rule can indeed be regarded as a fair settlement procedure, its fairness being understood in the loose and least controversial sense of the most minimal sacrifice or compromise to be made to reach convergence or, in other words, in the sense of the maximal decisiveness compatible with the equality of others. 